\title{
Comparison of Lead Tolerance and Accumulation Characteristics of Fourteen Herbaceous Plants
}

\author{
Xiongfei Cai, Xinjie Yu, Li Lei, Bin Xuan, Ji Wang†, Lingyun Zhang and Shijie Zhao \\ School of Geographic and Environmental Sciences, Guizhou Normal University, Guiyang, 550025, China \\ $†$ Corresponding author: Ji Wang: chuliu0610@163.com
}

Nat. Env. \& Poll. Tech.

Website: www.neptjournal.com

Received: 08-12-2019

Revised: 02-01-2020

Accepted: 28-03-2020

Key Words:

Lead tolerance

Accumulation characteristics

Phytoremediation

Herbaceous plants

\begin{abstract}
To compare lead $(\mathrm{Pb})$ tolerance and accumulation characteristics, 14 herbaceous plants were treated with different concentrations of lead $\left(0 \mathrm{mg} \cdot \mathrm{kg}^{-1}, 500 \mathrm{mg} \cdot \mathrm{kg}^{-1}, 1000 \mathrm{mg} \cdot \mathrm{kg}^{-1}, 1500 \mathrm{mg} \cdot \mathrm{kg}^{-1}, 2000 \mathrm{mg} \cdot \mathrm{kg}^{-1}\right)$ through an indoor pot experiment. Results indicated that the shoot dry weights (DWs), tolerance index (TI) and root tolerance index (RTI) of 14 herbaceous plants decreased with the increase of lead concentration. After comprehensive evaluation, Campsis grandiflora, Polygonum lapathifolium, Lolium perenne, and Poa annua were confirmed as tolerant plants to be cultivated in lead-zinc mining area. Moreover, shoots of the Rudbeckia hirta could effectively absorb the lead (I I) with the bioconcentration factor (BCF) of 2.29. The translocation factor (TF) of 6 herbaceous plants were larger than 1.0. They are: Polygonum lapathifolium (3.04) > Medicago sativa (2.49) > Rudbeckia hirta (1.72) > Talinum paniculatum (1.44) > Capsicum annuum cv. 276 (1.36) > Trifolium repens (1.21. Finally, after integration the BCF, TF and repair potential indices, we found that Rudbeckia hirta had a good restoration potential and its lead cumulation in the shoot was the highest $(2.576 \mathrm{mg}$ per plant) when the concentration was up to $1000 \mathrm{mg} \cdot \mathrm{kg}^{-1}$. Therefore, Rudbeckia hirta could be identified as a pioneer species of $\mathrm{Pb}$ hyperaccumulator.
\end{abstract}

\section{INTRODUCTION}

Lead is the most prevalent heavy metal contaminant and a human carcinogen (Ozkan et al. 2005, Guo et al. 2016). Over the past 50 years, approximately 783 thousand tons of lead have been reported to be entering the environment, especially the soil (Cui et al. 2013). Soil lead pollution disrupts the normal function of the ecosystem and poses a huge risk to human health. Cleaning up contaminated soil is a major challenge in environmental engineering.

Despite soil remediation techniques are numerous, most of them require high cost, intensive labour and may cause irreversible soil disturbances (Bhargava et al. 2012). Phytoremediation can provide efficient, cost-effective, and environmentally friendly remediation methods for the decontamination of heavy metal-polluted soils. Therefore, screening hyperaccumulators and tolerant species is a key step in the phytoremediation of soils (Mahdavian et al. 2017). Nowadays scientists found that the hyper-accumulators are mostly small biomass plants, and the most suitable hyperaccumulators are often the dominant plants in contaminated areas (Gao et al. 2014, Qin et al. 2013). Some studies show that the families of Gramineae, Compositae, Leguminosae, Cruciferae, Cyperus, and Pteridaceae in metal mining areas are prominent in accumulation and translocation (Nie et al. 2004). Sesbania drummondii (Sahi et al. 2002, Sharma et al.
2004), Hemidesmus indicus (Chandra et al. 2005), Arabis paniculata (Tang et al. 2009), and Plantago orbignyana (Bech et al. 2011) have been successfully used for phytoremediation of lead-zinc mines in some areas (Srivastava et al. 2014, Li et al. 2015). However, only a few studies focus on lead tolerant plants in southwestern China. As the distribution of plant resources is regional and temporal, screening out hyperaccumulators of high biomass and strong resistance for phytoremediation become practical.

We have selected 14 plant species in the southwest of China based on previous research to carry out seed germination indoor and experiment on plants' response to lead stress. The objectives of the study included: (1) evaluate and compare the effect of different application rates of lead on the growth; and (2) finding more hyperaccumulators through the evaluation and comparison of lead tolerance and accumulation traits of 14 plant species.

\section{MATERIALS AND METHODS}

\section{Pot Experiment}

Seeds of fourteen plant species were collected from areas surrounding Xiangbao mountain (Lat. 26 $11^{\circ}-27^{\circ} 22^{\prime} \mathrm{N}$, Long. $106^{\circ} 07^{\prime}-107^{\circ} 11^{\prime} \mathrm{E}$ ) in Guiyang city because there is a decades-year-old coal mine. The species sampled were 
from 6 families and 14 genera, including Cynodon dactylon (L.) Pers., Lolium perenne L., Poa annua L., Aster ageratoides Turcz. var. laticorymbus (Vant.) Hand.-Mazz., Rudbeckia hirta L., Cosmos sulphureus Cav., Gynura bicolor L., Capsicum annuum cv.276, Trifolium repens, Medicago sativa L., Calendula officinalis, Bidens pilosa L., Polygonum lapathifolium L. and Talinum paniculatum (Jacq.) Gaertn. Seeds were germinated in an incubator at $25 \pm 1$. After 7 days, seedlings were planted in individual pots. Soils were taken from the nearby farmland of Guizhou Normal University. Soil properties were as follows, $\mathrm{pH}$ : 7.36, organic matter: $31.24 \mathrm{~g} \cdot \mathrm{kg}^{-1}$, nitrogen $(\mathrm{N}): 213.52 \mathrm{mg} \cdot \mathrm{kg}^{-1}$, phosphorus $(\mathrm{P})$ : $4.53 \mathrm{mg} \cdot \mathrm{kg}^{-1}$ and potassium (K): $4.27 \mathrm{mg} \cdot \mathrm{kg}^{-1}$. Fertilization was not necessary during the growth stage. Five seedlings were planted in a $15 \mathrm{~cm} \times 18 \mathrm{~cm}$ pot with $1 \mathrm{~kg}$ of soil, which contains lead (heavy metal) acetate $\left[\mathrm{Pb}\left(\mathrm{CH}_{3} \mathrm{COO}\right)_{2} \cdot 3 \mathrm{H}_{2} \mathrm{O}\right.$; $0,500,1000,1500$ and $\left.2000 \mathrm{mg} \cdot \mathrm{kg}^{-1}\right]$. After 90 days of treatment, plant samples were drawn for observations.

\section{Chemical Analysis}

The plant samples were divided into roots and shoots before rinsed thoroughly with tap water and distilled water to remove adhering soil particles and sewage. Shoot height (the distance between the base of the tallest leaf and the tip of the lamina) and root length were measured. For dry weight determination, the cleaned samples were oven-dried at $105^{\circ} \mathrm{C}$ for $15 \mathrm{~min}$ and $70^{\circ} \mathrm{C}$ until constant weight. After their weight was recorded, dried plant samples were ground to pass a 1 mm mesh sieve, and wet digested in an $\mathrm{HNO}_{3} / \mathrm{HClO}_{4}(5: 1)$ mixture (Wu et al. 2010). The samples were analysed on an atomic absorption spectrophotometer, model ZEEnit 700P. The accuracy of the method was verified by analysing certified reference material (GBW 07604 - Poplar leaves) from the National Centre for Standard Materials (Beijing China).

\section{Data Processing}

One-way analysis of variance (ANOVA) was used to test the effects of the different valuables on the measured factors. Duncan's multiple range test was used to compare means when a significant variation was highlighted by the analysis of variance. SPSS 22.0 software and Origin 9.1 software were used for data processing. Bioconcentration factor $(\mathrm{BCF})$, translocation factor (TF), single index of lead tolerance factor (SILTF) and metal accumulation in the shoot of plants (MASP) were calculated based on the following formulas:

$$
\begin{gathered}
\mathrm{BCF}=[\text { Metal }] \text { shoot } /[\text { Meter }] \text { soil } \\
\mathrm{TF}=[\text { Metal }] \text { shoot } /[\text { Metal }] \text { root }
\end{gathered}
$$

$\mathrm{SILTF}=[$ Determination of indicators $]$ average/ [Control determination]

MASP $=[$ Metal $]$ shoot $\times[$ Biomass $]$ shoot

\section{Evaluation Methods}

A comprehensive evaluation of lead tolerance of plants was conducted with Membership Function Method and Standard Deviation Coefficient (Li et al. 2009, Li et al. 2015). Related formulas can be expressed as follows:

(1) Using membership function to standardize the indicators:

$$
\mu\left(X_{i j}\right)=\left(\bar{X}_{i j}-X_{j \min }\right) /\left(X_{j \max }-X_{j \min }\right)
$$

where $\mu\left(X_{i j}\right)$ is the membership function of index $\mathrm{j}$ of class $\mathrm{i} ; \bar{X}_{i j}$ is the average measured value of index $\mathrm{j}$ of class i, $X_{j \min }$ and $X_{j \max }$ and denote the minimum and maximum values of index $j$.

(2) Determination of weight:

$$
\begin{gathered}
V_{i j}=\sqrt{\sum_{i=1}^{m}\left[\mu\left(X_{i j}\right)-\mu\left(\bar{X}_{i j}\right)\right]^{2}} / \mu\left(\bar{X}_{i j}\right) \\
W_{i j}=V_{i j} / \sum_{j=1}^{n} V_{i j}
\end{gathered}
$$

Where, $V_{i j}$ is the standard deviation coefficient of each index; $W_{i j}$ is the weight coefficient of each index.

(3) The calculation of D, the comprehensive evaluation value:

$$
D=\sum_{j=1}^{n}\left[\mu\left(X_{i j}\right) \cdot W_{i j}\right]
$$

Where, D refers to the comprehensive evaluation value of all indices. It is used to measure the lead tolerance.

\section{RESULTS}

\section{Tolerance Analysis of $\mathbf{P b}$}

Different shoot dry weights (DWs) under changing lead concentrations are given in Table 1 . Under the lead concentration of $500 \mathrm{mg} \cdot \mathrm{kg}^{-1}$, DWs of 14 plant species do not change significantly, indicating that the plants were free of this level of poison. The shoot biomass of Rudbeckia hirta, Cosmos sulphureus, Gynura bicolor, Capsicum annum cv.276 and Bidens pilosa decreased considerably under $1,000,1,500$ and $2,000 \mathrm{mg} \cdot \mathrm{kg}^{-1}$ of lead concentrations. The shoot biomass of Cynodon dactylon, Lolium perenne, Poa апnиа, Aster ageratoides and Trifolium repens decreased substantially under 1,500 and $2,000 \mathrm{mg} \cdot \mathrm{kg}^{-1}$ of lead concentrations. In contrast, no significant change was observed in the shoot biomass of Medicago sativa, Calendula officinalis, Polygonum lapathifolium and Talinum paniculatum under all lead concentrations.

The tolerance index (TI) is the ratio of shoot dry weights of the treatment group to the control group. TI greater than 
Table 1: Shoot dry weights under different lead concentrations.

\begin{tabular}{|c|c|c|c|c|c|}
\hline \multirow[t]{2}{*}{ Species } & \multicolumn{5}{|c|}{ Shoot dry weight under different lead concentrations $\left(\mathrm{g} \cdot \mathrm{pot}^{-1}\right)$} \\
\hline & $\mathrm{CK}$ & $500 \mathrm{mg} \cdot \mathrm{kg}^{-1}$ & $1000 \mathrm{mg} \cdot \mathrm{kg}^{-1}$ & $1500 \mathrm{mg} \cdot \mathrm{kg}^{-1}$ & $2000 \mathrm{mg} \cdot \mathrm{kg}^{-1}$ \\
\hline Cynodon dactylon & $3.23 \pm 0.08^{\mathrm{a}}$ & $3.06 \pm 0.25^{\mathrm{a}}$ & $3.18 \pm 0.21^{\mathrm{a}}$ & $2.17 \pm 0.13^{b}$ & $1.97 \pm 0.27^{b}$ \\
\hline Lolium perenne & $2.73 \pm 0.04^{\mathrm{a}}$ & $2.97 \pm 0.16^{\mathrm{a}}$ & $2.31 \pm 0.25^{\mathrm{a}}$ & $1.89 \pm 0.32^{\mathrm{b}}$ & $1.39 \pm 0.21^{\mathrm{c}}$ \\
\hline Роа аппиа & $1.88 \pm 0.45^{\mathrm{a}}$ & $1.82 \pm 0.13^{\mathrm{a}}$ & $1.53 \pm 0.12^{\mathrm{a}}$ & $0.89 \pm 0.19^{b}$ & $0.67 \pm 0.10^{\mathrm{b}}$ \\
\hline Aster ageratoides & $2.31 \pm 0.25^{\mathrm{a}}$ & $2.07 \pm 0.12^{\mathrm{a}}$ & $1.82 \pm 0.13^{\mathrm{b}}$ & $0.98 \pm 0.31^{\mathrm{c}}$ & - \\
\hline Rudbeckia hirta & $3.97 \pm 0.23^{\mathrm{a}}$ & $2.19 \pm 0.04^{\mathrm{ab}}$ & $1.32 \pm 0.12^{\mathrm{b}}$ & $1.61 \pm 0.17^{\mathrm{b}}$ & $1.13 \pm 0.18^{\mathrm{c}}$ \\
\hline Cosmos sulphureus & $2.03 \pm 0.02^{\mathrm{a}}$ & $1.86 \pm 0.16^{\mathrm{a}}$ & $1.21 \pm 0.06^{\mathrm{b}}$ & $1.09 \pm 0.24^{\mathrm{b}}$ & $1.31 \pm 0.07^{\mathrm{b}}$ \\
\hline Gynura bicolor & $1.51 \pm 0.09^{\mathrm{a}}$ & $1.36 \pm 0.17^{\mathrm{a}}$ & $1.25 \pm 0.03^{\mathrm{ab}}$ & $1.1 \pm 0.26^{\mathrm{b}}$ & $0.96 \pm 0.19^{\mathrm{b}}$ \\
\hline Capsicum аппиит cv.276 & $3.02 \pm 0.30^{\mathrm{a}}$ & $2.78 \pm 0.35^{\mathrm{a}}$ & $2.36 \pm 0.12^{\mathrm{b}}$ & $1.73 \pm 0.11^{\mathrm{c}}$ & - \\
\hline Trifolium repens & $1.98 \pm 0.17^{\mathrm{a}}$ & $2.17 \pm 0.36^{\mathrm{a}}$ & $1.85 \pm 0.23^{\mathrm{a}}$ & $1.3 \pm 0.15^{\mathrm{b}}$ & $0.95 \pm 0.18^{\mathrm{c}}$ \\
\hline Medicago sativa. & $1.77 \pm 0.16^{\mathrm{a}}$ & $1.58 \pm 0.17^{\mathrm{a}}$ & $1.35 \pm 0.03^{\mathrm{a}}$ & $1.27 \pm 0.23^{\mathrm{ab}}$ & $1.15 \pm 0.22^{\mathrm{b}}$ \\
\hline Calendula officinalis & $2.56 \pm 0.24^{\mathrm{a}}$ & $2.1 \pm 0.31^{\mathrm{a}}$ & $1.83 \pm 0.06^{\mathrm{a}}$ & $1.95 \pm 0.28^{\mathrm{a}}$ & $1.69 \pm 0.32^{\mathrm{b}}$ \\
\hline Bidens pilosa & $5.53 \pm 0.39^{\mathrm{a}}$ & $5.41 \pm 0.32^{\mathrm{a}}$ & $6.33 \pm 0.45^{\mathrm{b}}$ & $5.1 \pm 0.27^{\mathrm{a}}$ & $4.17 \pm 0.19^{c}$ \\
\hline Polygonum lapathifolium & $1.87 \pm 0.03^{\mathrm{a}}$ & $1.85 \pm 0.24^{\mathrm{a}}$ & $0.99 \pm 0.15^{\mathrm{b}}$ & $1.32 \pm 0.09^{\mathrm{ab}}$ & $1.27 \pm 0.06^{\mathrm{ab}}$ \\
\hline Talinum paniculatum & $0.61 \pm 0.04^{\mathrm{a}}$ & $0.55 \pm 0.12^{\mathrm{a}}$ & $0.6 \pm 0.15^{\mathrm{a}}$ & $0.65 \pm 0.11^{\mathrm{a}}$ & $0.63 \pm 0.06^{\mathrm{a}}$ \\
\hline
\end{tabular}

Note: Different letters indicate a significant difference between the different treatments of the same plant (mean \pm S.D, $p<0.05, n=5$ ).

0.5 indicates the plant grows well and has a good tolerance (Wu et al. 2017). The root tolerance index (RTI) is the ratio of the average root length of each treatment group to the control group. Generally, RTI greater than 0.9 indicates that the root growth of the plant is not significantly inhibited (Chehregani et al. 2009). Therefore, TI and RTI can be used as an important index of plant heavy metal tolerance.

According to the TI and RTI values under different lead concentration (Table 2), it is shown that Cynodon dactylon, Lolium perenne, Cosmos sulphureus, Gynura bicolor, Calendula officinalis and Polygonum lapathifolium had good tolerance for lead stress, and their TI and RTI values were greater than 0.5 and 0.9 in all treatments. As the lead concentration increased in the treatment group, both TI and RTI of these 14 plants gradually declined. TI of Pоа апnиа, Rudbeckia hirta and Trifolium repens gradually decreased with the increase of lead concentrations to 0.5. But most of the plants showed significant damage at the lead concentration of $2000 \mathrm{mg} \cdot \mathrm{kg}^{-1}$, and the RTI values gradually began to be less than 0.9; furthermore, Aster ageratoides, Capsicum annuит cv.276 were killed at the lead concentration of 2000 $\mathrm{mg} \cdot \mathrm{kg}^{-1}$. When evaluated from DW, TI and RTI together, the Polygonum lapathifolium showed a strong tolerance and no obvious signs of damage under all treatments.

\section{Characteristics of Lead Accumulation}

The lead concentration in shoot and root of 14 herbaceous plants were analysed by variance analysis (Fig. 1). The aerial part results demonstrated that most plants were significantly affected by the increase in lead concentrations. However, the lead concentration in shoots of Rudbeckia hirta, Trifolium repens and Polygonum lapathifolium increased and then stabilise before slowly declining. Therefore, the lead concentration in shoots did not maintain growth but slowed down or even declined when it exceeded the tolerance concentration, due to inhibition effects. At the initial concentration, no significant difference was observed on the lead concentration in shoots and roots. As lead concentrations increased, most roots have higher lead concentration than shoots.

Under the treatments of $1000 \mathrm{mg} \cdot \mathrm{kg}^{-1}$ and $1500 \mathrm{mg} \cdot \mathrm{kg}^{-1}$, no significant change of lead concentration in shoots was observed, except for Cynodon dactylon, Cosmos sulphureus, Capsicum annuum cv.276, and Medicago sativa. When the treatment exceeded $500 \mathrm{mg} \cdot \mathrm{kg}^{-1}$, Cynodon dactylon, Aster ageratoides, Rudbeckia hirta, Gynura bicolor, Capsicum annuum cv.276 and Trifolium repens would have a substantially higher lead concentration in shoots compared with the control group. When the treatment exceeded $1000 \mathrm{mg} \cdot \mathrm{kg}^{-1}$, Lolium perenne, Poa annua, Cosmos sulphureus, Medicago sativa and Calendula officinalis would have a substantially higher lead concentration in shoots compared with the control group. It is not until the treatment exceeding $1500 \mathrm{mg} \cdot \mathrm{kg}^{-1}$ when Bidens pilosa and Polygonum lapathifolium started to show significantly higher lead concentration in shoots than that in the control. The lead accumulation in shoots of the Rudbeckia hirta and Capsicum annuum cv.276 passed the critical value of $1000 \mathrm{mg} \cdot \mathrm{kg}^{-1}$ when they were treated with $1,000 \mathrm{mg} \cdot \mathrm{kg}^{-1}$ of lead concentration. It was noted that the lead concentration in the shoots of Rudbeckia hirta had already exceeded the critical value when it was under the 
Table 2: Tolerance index and root tolerance index of 14 species of plants under different lead gradient.

\begin{tabular}{|c|c|c|c|c|c|c|c|c|}
\hline \multirow[t]{3}{*}{ Species } & \multicolumn{8}{|c|}{ Tolerance index and Root tolerance index } \\
\hline & \multicolumn{2}{|c|}{$500 / \mathrm{mg} \cdot \mathrm{kg}^{-1}$} & \multicolumn{2}{|c|}{$1000 / \mathrm{mg} \cdot \mathrm{kg}^{-1}$} & \multicolumn{2}{|c|}{$1500 / \mathrm{mg} \cdot \mathrm{kg}^{-1}$} & \multicolumn{2}{|c|}{$2000 / \mathrm{mg} \cdot \mathrm{kg}^{-1}$} \\
\hline & TI & RTI & TI & RTI & TI & RTI & TI & RTI \\
\hline Cynodon dactylon & 0.95 & 0.96 & 0.98 & 0.96 & 0.67 & 0.94 & 0.61 & 0.92 \\
\hline Lolium perenne & 1.09 & 1 & 0.85 & 0.96 & 0.69 & 0.96 & 0.51 & 0.94 \\
\hline Роа аппиа & 0.97 & 0.97 & 0.81 & 0.97 & 0.47 & 0.92 & 0.36 & 0.92 \\
\hline Aster ageratoides & 0.90 & 0.98 & 0.79 & 0.98 & 0.42 & 0.93 & - & - \\
\hline Rudbeckia hirta & 0.55 & 1 & 0.33 & 0.96 & 0.41 & 0.93 & 0.28 & 0.89 \\
\hline Cosmos sulphureus & 0.92 & 1.02 & 0.60 & 1.05 & 0.54 & 0.96 & 0.65 & 0.91 \\
\hline Gynura bicolor & 0.90 & 0.99 & 0.83 & 0.98 & 0.73 & 0.95 & 0.64 & 0.95 \\
\hline Capsicum аппиит cv.276 & 0.92 & 1.02 & 0.78 & 1.04 & 0.57 & 1 & - & - \\
\hline Trifolium repens & 1.10 & 1 & 0.93 & 1.02 & 0.66 & 0.93 & 0.48 & 0.86 \\
\hline Medicago sativa & 0.89 & 0.93 & 0.76 & 0.98 & 0.72 & 0.95 & 0.65 & 0.88 \\
\hline Calendula officinalis & 0.82 & 1 & 0.71 & 0.96 & 0.76 & 0.95 & 0.66 & 0.92 \\
\hline Bidens pilosa & 0.98 & 1 & 1.14 & 1.03 & 0.92 & 1 & 0.75 & 0.86 \\
\hline Polygonum lapathifolium & 0.99 & 0.99 & 0.53 & 0.99 & 0.71 & 0.99 & 0.68 & 0.97 \\
\hline Talinum paniculatum & 0.90 & 1 & 0.98 & 0.94 & 1.07 & 0.91 & 1.03 & 0.85 \\
\hline
\end{tabular}

$500 \mathrm{mg} \cdot \mathrm{kg}^{-1}$ treatment, with the highest average lead concentration of $1783 \mathrm{mg} \cdot \mathrm{kg}^{-1}$.

The bioconcentration factor $(\mathrm{BCF})$ and translocation factor (TF) of 14 plants under different concentrations are shown in Fig. 2. The results indicated that Lolium perenne, Aster ageratoides, Bidens pilosa and Polygonum lapathifolium showed no significant change in BCF under all treatments. Except for Cynodon dactylon and Capsicum annuum cv.276, BCF of other plants decreased with the increase of lead treatment. TF of Poa annua and Aster ageratoides showed no significant difference at all concentrations. However, TF of Lolium perenne, Rudbeckia hirta, Cosmos sulphureus, Gynura bicolor and Trifolium repens decreased with the increase of lead treatment.

Among 14 plants, only Rudbeckia hirta's BCF was more than 1.0 at both the concentrations of $500 \mathrm{mg} \cdot \mathrm{kg}^{-1}$ and 1000 $\mathrm{mg} \cdot \mathrm{kg}^{-1}$. When the Capsicum annuum cv.276 was treated with $1500 \mathrm{mg} \cdot \mathrm{kg}^{-1}$ lead concentration, Medicago sativa was treated at $1000 \mathrm{mg} \cdot \mathrm{kg}^{-1}$, and Rudbeckia hirta, Trifolium repens and Talinum paniculatum were treated at $500 \mathrm{mg} \cdot \mathrm{kg}^{-1}$, their TFs were more than 1.0, indicating that lead transport capacity of plants was closely related to their tolerance.

Different capital letters meant a significant difference of translocation factors at 0.05 level among treatments

\section{Comprehensive Evaluation of Lead Tolerance for 14 Plants}

The lead tolerance of 14 plant species was sorted according to the standard deviation coefficient. Six indicators of plant height, root length, shoot and root biomass and lead absorption were considered. Besides, lead tolerance coefficients, subordination and $D$ value of comprehensive evaluation were calculated (Table 3). Based on the results, the comprehensive lead tolerance for 14 plants were as follows: Trifolium repens $>$ Polygonum lapathifolium $>$ Lolium perenne $>$ Poа anпиa $>$ Aster ageratoides $>$ Bidens pilosa $>$ Cosmos sulphureus $>$ Cynodon dactylon $>$ Medicago sativa $>$ Gynura bicolor $>$ Capsicum annuum cv. $276>$ Rudbeckia hirta $>$ Calendula officinalis $>$ Talinum paniculatum.

Among 14 herbaceous plants, Rumex acetosa showed a strong tolerance. Shi et al. (2007) used four indicators, including lead concentration in shoots, lead concentration in roots, RTI and BCF, to evaluate the lead tolerance of 3 gramineous forages. They reached the following conclusion of lead tolerance orders: Lolium perenne $>$ Poa annua $>C y$ nodon dactylon. According to the comprehensive evaluation results, the uptake of lead in the root systems of Trifolium repens and Polygonum lapathifolium was low at various concentrations. They showed a strong resistance to lead. In contrast, the advantages of Lolium perenne and Poa апnиa included higher capacity in lead absorption and adaptation. Therefore, these plants with exclusion and accumulation characteristics could be cultivated together as tolerant plants in the lead-zinc mining area.

\section{DISCUSSION}

Tolerance mechanisms for heavy metals vary in different plants. Even the same species of plants will react in differ- 

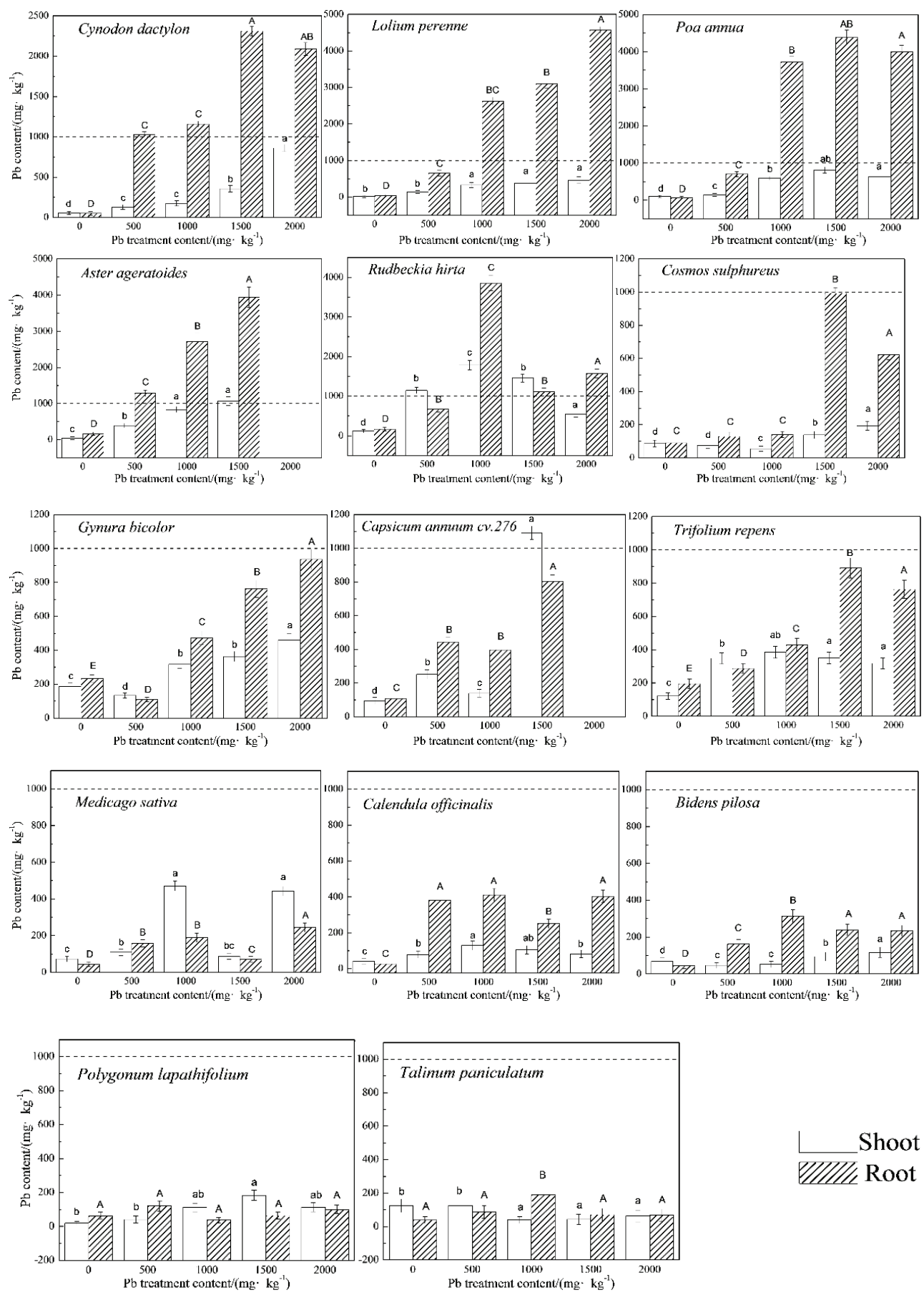

Shoot

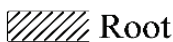

Note: Different small letters meant a significant difference of shoot lead content at 0.05 level among treatments; Different capital letters meant a significant difference of root lead content at 0.05 level among treatment

Fig. 1: Shoot and root lead accumulation under different lead concentrations.

ent ways at different concentrations of heavy metals. The biomass of Trifolium repens and Lolium perenne increased at $500 \mathrm{mg} \cdot \mathrm{kg}^{-1}$ of lead treatment, indicating that low lead concentration could promote growth. Liu et al. (2006) have also found that lead concentrations below $200 \mathrm{mg} \cdot \mathrm{kg}^{-1}$ will promote the root growth of cucumber seedlings. It might be caused by organic acids excreted by the plants under the stimulus of heavy metals at low concentrations. Organic 

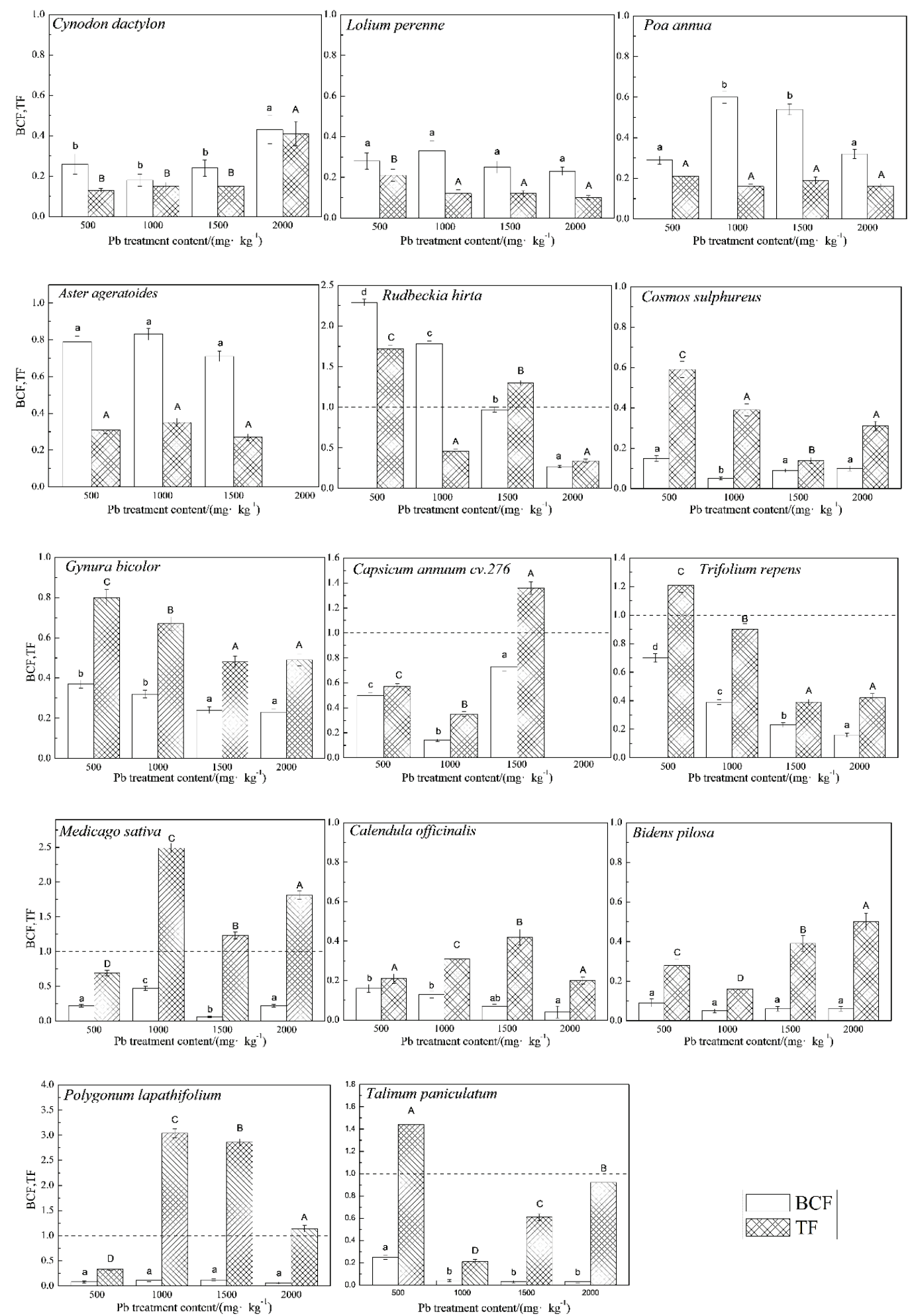

Note: Different small letters meant a significant difference in shoot bioaccumulation factors at 0.05 level among treatments;

Fig. 2: Shoot bioaccumulation and translocation factors under different $\mathrm{Pb}$ concentrations. 
Table 3: The single lead tolerances coefficient, subordination value and D value of comprehensive evaluation.

\begin{tabular}{|c|c|c|c|c|c|c|c|c|c|c|c|c|c|}
\hline \multirow[b]{2}{*}{ Plants } & \multicolumn{6}{|c|}{ Resistance to each index lead coefficient } & \multicolumn{6}{|c|}{ Membership function value } & \multirow[b]{2}{*}{$\begin{array}{l}\text { D val- } \\
\text { ues }\end{array}$} \\
\hline & $\begin{array}{l}\text { Plant } \\
\text { height }\end{array}$ & $\begin{array}{l}\text { Root } \\
\text { length }\end{array}$ & $\begin{array}{l}\text { Shoots } \\
\text { bio- } \\
\text { mass }\end{array}$ & $\begin{array}{l}\text { Root } \\
\text { bio- } \\
\text { mass }\end{array}$ & $\begin{array}{l}\text { Shoots } \\
\text { lead ab- } \\
\text { sorption }\end{array}$ & $\begin{array}{l}\text { Root } \\
\text { lead } \\
\text { absorp- } \\
\text { tion }\end{array}$ & $\mu(1)$ & $\mu(2)$ & $\mu(3)$ & $\mu(4)$ & $\mu(5)$ & $\mu(6)$ & \\
\hline $\begin{array}{l}\text { Cynodon } \\
\text { dactylon }\end{array}$ & 0.87 & 0.70 & 0.80 & 0.89 & 5.71 & 26.03 & 0.639 & 0.450 & 0.597 & 0.625 & 0.323 & 0.576 & 0.504 \\
\hline Lolium perenne & 0.89 & 0.72 & 0.78 & 0.83 & 22.28 & 56.98 & 0.722 & 0.533 & 0.549 & 0.555 & 0.559 & 0.477 & 0.568 \\
\hline Роа аппиа & 0.96 & 0.70 & 0.65 & 0.82 & 3.15 & 37.46 & 0.576 & 0.440 & 0.569 & 0.564 & 0.501 & 0.581 & 0.542 \\
\hline $\begin{array}{l}\text { Aster } \\
\text { ageratoides }\end{array}$ & 0.85 & 0.70 & 0.76 & 0.97 & 3.26 & 3.21 & 0.574 & 0.560 & 0.442 & 0.582 & 0.411 & 0.486 & 0.486 \\
\hline $\begin{array}{l}\text { Rudbeckia } \\
\text { hirta }\end{array}$ & 0.96 & 0.70 & 0.79 & 0.86 & 2.50 & 2.63 & 0.480 & 0.628 & 0.574 & 0.587 & 0.694 & 0.457 & 0.569 \\
\hline $\begin{array}{l}\text { Cosmos } \\
\text { sulphureus }\end{array}$ & 0.86 & 0.70 & 0.39 & 0.54 & 8.48 & 8.99 & 0.625 & 0.600 & 0.322 & 0.331 & 0.535 & 0.355 & 0.450 \\
\hline Gynura bicolor & 0.84 & 0.71 & 0.74 & 0.58 & 2.11 & 11.11 & 0.435 & 0.550 & 0.436 & 0.172 & 0.524 & 0.697 & 0.523 \\
\hline $\begin{array}{l}\text { Capsicum } \\
\text { aпnиum cv.276 }\end{array}$ & 0.95 & 0.73 & 0.67 & 1.18 & 1.27 & 4.39 & 0.591 & 0.880 & 0.264 & 0.273 & 0.398 & 0.338 & 0.411 \\
\hline $\begin{array}{l}\text { Trifolium } \\
\text { repens }\end{array}$ & 1.00 & 0.73 & 0.95 & 0.87 & 1.12 & 4.53 & 0.516 & 0.671 & 0.527 & 0.619 & 0.410 & 0.573 & 0.528 \\
\hline $\begin{array}{l}\text { Medicago } \\
\text { sativa }\end{array}$ & 0.94 & 0.72 & 0.77 & 0.60 & 1.56 & 2.16 & 0.400 & 0.500 & 0.502 & 0.459 & 0.487 & 0.476 & 0.474 \\
\hline $\begin{array}{l}\text { Calendula } \\
\text { officinalis }\end{array}$ & 0.84 & 0.64 & 0.70 & 0.75 & 12.95 & 12.00 & 0.533 & 0.500 & 0.612 & 0.610 & 0.527 & 0.492 & 0.531 \\
\hline Bidens pilosa & 0.85 & 0.74 & 0.73 & 0.90 & 3.52 & 3.18 & 0.364 & 0.600 & 0.534 & 0.585 & 0.495 & 0.661 & 0.557 \\
\hline $\begin{array}{l}\text { Polygonum } \\
\text { lapathifolium }\end{array}$ & 1.26 & 0.68 & 0.76 & 0.74 & 4.17 & 4.05 & 0.698 & 0.417 & 0.576 & 0.521 & 0.300 & 0.474 & 0.454 \\
\hline $\begin{array}{l}\text { Talinum } \\
\text { paniculatum }\end{array}$ & 0.85 & 0.68 & 1.00 & 1.24 & 0.63 & 2.33 & 0.584 & 0.600 & 0.580 & 0.356 & 0.462 & 0.343 & 0.444 \\
\hline Weights & & & & & & & 0.10 & 0.08 & 0.08 & 0.12 & 0.30 & 0.32 & \\
\hline
\end{tabular}

acids will stimulate the root growth of plants. However, when lead concentration becomes high, the plant biomass begins to decline due to growth inhibition. In this experiment, when the lead concentration of the treatment reached $2000 \mathrm{mg} \cdot \mathrm{kg}^{-1}$, the biomass of Cynodon dactylon, Poa annua, Trifolium repens, Rudbeckia hirta, Calendula officinalis, Bidens pilosa and Gynura bicolor dropped sharply to $63.68 \%, 43.70 \%, 53.54 \%, 32.22 \%, 64.34 \%, 68.87 \%$ and $51.97 \%$ of the biomass of CK, respectively. Studies show that when the soil contains a high concentration of lead, the uptake of lead in plants will reach saturation. As the lead absorbed by roots is difficult to transport to the shoots due to the root adsorption, passivation or precipitation in cells, the toxicity accumulate and inhibit the absorption of macroelements such as $\mathrm{K}, \mathrm{Ca}, \mathrm{Mg}$, and trace elements, such as $\mathrm{Fe}, \mathrm{Cu}, \mathrm{Zn}$. As a result, plants grow slowly or die from the lack of nutrients (Seregin et al. 2008, Akinci et al. 2010, Wang et al. 2010 and Liu et al. 2016).

A hyperaccumulator is a plant capable of growing in soils with very high concentrations of metals, absorbing these metals through their roots, and concentrating extremely high levels of metals in their tissues (Brooks et al. 1997, Sun et al. 2008). According to Baker (1981), there are three indicators to define a $\mathrm{Pb}$-hyperaccumulator: (a) the threshold value of metal accumulated in the shoots of the plant is up to $1000 \mathrm{mg} \cdot \mathrm{kg}^{-1}$; (b) both bioconcentration factor (BCF) index, the proportion in the shoot of the plant to the soil, and translocation factor (TF) index, the proportion of metal concentration in shoots to roots, are greater than 1 ; and (c) the hyperaccumulator should have great tolerance capability; the shoot biomass of a hyperaccumulator should not decrease significantly when the concentration of heavy metals reach the critical value. Among 14 plants tested in this experiment, only Rudbeckia hirta meet the three conditions. Current hyperaccumulator plants have disadvantages such as small biomass, slow growth and low translocation capacity of heavy metals. Therefore, the total accumulation of heavy metals at the part of the plant above ground is a key factor 


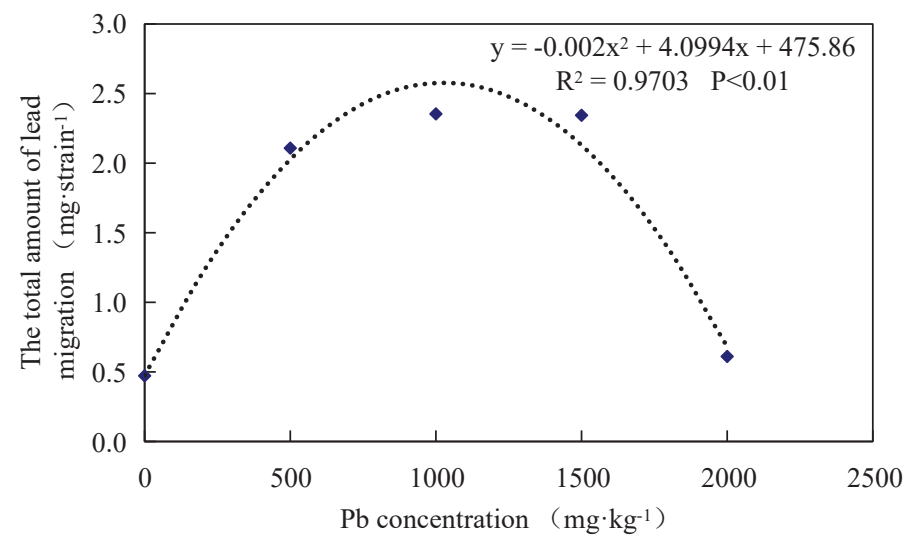

Fig. 3: Total lead concentration accumulated in shoots of Rudbeckia hirta versus different treatments.

to evaluate the potential of a hyperaccumulator (Monni et al. 2000, Lasat et al. 1988).

It can be seen from Fig. 3 that the total amount of lead in shoots of the Rudbeckia hirta is as per the binomial fitting curve and $\mathrm{R}^{2}=0.9703$. According to the fitting curve, there was a sharp increase in the total accumulation of lead in shoots of the Rudbeckia hirta and then the percentage gradually went down. In the vicinity of $1000 \mathrm{mg} \cdot \mathrm{kg}^{-1}$, the cumulative total reached a saturated state, and after reaching the critical value, the cumulative amount begins to decrease. According to the fitting equation, when the soil lead concentration was $1025 \mathrm{mg} \cdot \mathrm{kg}^{-1}$, the lead concentrations in shoots of the Rudbeckia hirta was the highest at $2.576 \mathrm{mg} \cdot$ strain $^{-1}$, which was significantly higher than that of the control. Wang et al. (2005) have studied the total concentration of lead in Bidens maximowicziana Oett. at the same concentration. They found that the total amount of lead in the ground above was $0.3262 \mathrm{mg} \cdot \mathrm{strain}^{-1}$. Our experiment result on Rudbeckia hirta is 7.8 times than that of Bidens maximowicziana Oett, indicating that the tolerance and absorption of Rudbeckia hirta are better than that of Bidens maximowicziana Oett.

This study first proposes Rudbeckia hirta as a pioneer hyperaccumulator. We need to further confirm its function in the restoration of contaminated land and reduction of heavy metals' impacts on human health. Further research needs to be done for better understanding of the tolerance mechanism and restoration ability of Rudbeckia hirta.

\section{CONCLUSIONS}

Among fourteen herbaceous plants in this experiment, the lead tolerance ability of Trifolium repens was the strongest and Calendula officinalis was the worst; the bioconcentration factor of Rudbeckia hirta was above 2.29, indicating that it can effectively absorb lead in soil; the translocation factor of the six plants were greater than 1.0, and their transport capacity was: Polygonum lapathifolium (3.04) > Medicago sativa (2.49) > Rudbeckia hirta (1.72) > Talinum paniculatum $(1.44)>$ Capsicum annuum cv.276 (1.36) > Trifolium repens $(1.21)$.

Through the comprehensive evaluation of lead tolerance, Trifolium repens, Polygonum lapathifolium, Lolium perenne, Poa апnиa can be used as a tolerant plant to cultivate in the lead-zinc mining district. Rudbeckia hirta satisfies the requirements of the hyperaccumulator plant, which is a pioneer species of $\mathrm{Pb}$-hyperaccumulator plant. According to the repair potential index, Rudbeckia hirta has the best remediation potential. When the soil lead concentration was about $1000 \mathrm{mg} \cdot \mathrm{kg}^{-1}$, the total amount of lead accumulation in shoots was $2.576 \mathrm{mg} \cdot \mathrm{strain}^{-1}$.

\section{ACKNOWLEDGEMENTS}

This work was supported by The Key Project of Science and Technology Foundation, Guizhou Province (Qian Sci. Co. JZ, [2014], NO.2012), Guizhou Provincial Science Technology Support Program, Guizhou Province (Qian Sci. Co.[2017], No.2580), and Technology Foundation, Guizhou Province (Qian Sci. Co., [2019], NO.1231).

\section{REFERENCES}

Akinci, I. E., Akinci, S. and Yilmaz, K. 2010. Response of tomato (Solanum lycopersicum L.) to lead toxicity: Growth, element uptake, chlorophyll and water content. Afr. J. Agric Res., 5: 416-423.

Baker, A. J. M. 1981. Accumulators and excluders-strategies in the response of plants to heavy metals. J. Plant Nutr., 3: 643-654.

Brooks, R. R., Lee, J. and Reeves, R. D. 1997. Detection of nickliferous rocks by analysis of indicator plants. Journal Geochemical Exploration, 7: 49-77.

Bech, J., Duran, P., Roca, N., Poma, W., Sánchez, I., Barceló, J., Boluda, R., Roca-Pérez, L. and Poschenrieder, C. 2011. Shoot accumulation of several trace elements in native plant species from contaminated soil 
in the Peruvian Andes. J. Geochem., 113(1): 106-111.

Bhargava, A., Carmona, F.F., Bhargava, M. and Srivastava, S. 2012. Approaches for enhanced phytoextraction of heavy metals. J. Environ. Manage., 105: 103-120.

Chehregani, A., Noori, M. and Yazdi, H. L. 2009. Phytoremediation of heavy-metal-polluted soil: Screening for new accumulator plants in Angouran mine (Iran) and evaluation of removal ability. Ecotox. Environ. Safe., 72(5): 1349-1353.

Cui, S., Zhang, T. G., Zhao, S. L., Li, P., Zhou, Q. X., Zhang, Q. R. and Han, Q. 2013. Evaluation of three ornamental plants for phytoremediation of Pb-contaminated soil. Int. J. Phytoremediat., 15(4): 299-306.

Chandra, S. K., Kamala, C. T., Chary, N. S., Balaram, V. and Garcia, G. 2005. Potential of Hemidesmus indicus for phytoextraction of lead from industrially contaminated soil. Chemosphere, 58: 507-514.

Gao, H. Z., Guo, W. Z. and Bi, J. 2014. Study on lead tolerance and enrichment characteristics of 20 plants. Chinese Agricultural Science Bulletin, 30(19): 19-24 (in Chinese).

Guo, X. H., Zhu, G. L. and Wei, X. Z. 2016. Absorption, enrichment and transport of heavy metal lead in soil by five herbaceous plants. Research of Soil and Water Conservation, 23(1): 183-186 (in Chinese).

Li, Y., Liu, G. B. and Gao, H. W. 2009. Study on comprehensive evaluation of drought resistance of Medicago sativa L. Germplasm at seedling stage. Acta Agrestia Sinica, 17(6): 807-812 (in Chinese).

Li, H. F., Wang, Y., Yuan, Q. H. and Zhao, G. Q. 2015. Effects of lead stress on growth, physiology, and lead ion accumulation and transportation in gramineous forages. Acta Prataculturae Sinica, 24(9): 163-172 (in Chinese).

Liu, S. C., Xiao, L. T. and Liao, B. H. 2006. Relationship between lead stress and growth and endogenous phytohormones of cucumber seedlings. Journal of Agro-Environment Science, 25(3): 592-596 (in Chinese).

Liu, Y. J., Zhu, X. M. and Lin, L. J. 2016. Physiological responses and lead accumulation of the winter weed Capsella bursa-pastoris under lead stress. Journal of Agro-Environment Science, 35(1): 29-36 (in Chinese).

Lasat, M. M. and Fuhrman, M.1988. Phytoextraction of radiocesium-contaminated soil: evaluation of cesium bioaccumulation in the shoots of three plant species. J. Environ. Qual., 27: 160-165.

Monni, S. and Salemaa, M. 2000. Copper resistance of Calluna vulgaris originating from the pollution gradient of a $\mathrm{Cu}-\mathrm{Ni}$ smelter in southwest Finland. Environ. Pollut., 109: 211-221.

Mahdavian, K., Ghaderian, S. M. and Torkzadeh-Mahani, M. 2017. Accumulation and phytoremediation of $\mathrm{Pb}, \mathrm{Zn}$, and $\mathrm{Ag}$ by plants growing on Koshk lead-zinc mining area, Iran. Journal of Soil \& Sediments, 17: $1310-1320$.

Ozkan, M. H., Gurkan, R., Ozkan, A. and Akcay, M. 2005. Determination of manganese and lead in roadside soil samples by FAAS with ultrasound Assisted leaching. J. Anal. Chem., 60(5): 469-474.

Nie, J. H., Liu, X. M. and Wang, Q. R. 2004. Preparation of lead enrichment plant varieties. Chinese Journal of Agricultural Engineering, 20(4): 255-258 (in Chinese).

Qin, L., Zu, Y. Q., Li, Y. and Wang, J. 2013. Heavy metal contents and accumulation characteristic of seven wild plants from the slagheap surrounding of Huize lead-zinc tailings. Journal of Agro-Environment Science, 32(8): 1558-1563 (in Chinese).

Shi, R. J. and Lu, Y. G. 2007. Characteristics of lead uptake by four herbaceous in acid yellow soil. Journal of Soil and Water Conservation, 21(3): 73-76 (in Chinese).

Seregin, I. V. and Kosevnilove, A. D. 2008. Roles of root and shoot tissues in transport and accumulation of cadmium, lead, nickel and strontium. Russ. J. Plant Physiol., 55: 1-22.

Sun, Y. B., Zhou, Q. X. and Diao, C. Y. 2008. Effects of cadmium and arsenic on growth and metal accumulation of Cd-hyperaccumulator (Solanum nigrum L.). Bioresource Technol., 99: 1103-1110.

Sahi, S. V., Bryant, N. L., Sharma, N. C. and Singh, S. R. 2002. Characterization of a lead hyperaccumulator shrub, Sesbania drummondii. Environ. Sci. Technol., 36: 4676-4680.

Sharma, N. C., Gardea-Torresday, J. L. and Parson, S. V. 2004. Chemical speciation of lead in Sesbania drummondii. Environ. Toxicol. Chem., 23: 2068-2073.

Srivastava, J., Kalra, S. J. S. and Naraian, R. 2014. Environmental perspectives of Phragmites australis (Cav.) Trin. Ex. Steudel. Appl. Water Sci., 4: 193-202.

Tang, Y. T., Qiu, R. L., Zeng, X. W., Ying, R. R., Yu, F. M. and Zhou, X. Y. 2009. Lead, zinc cadmium accumulation and growth simulation in Arabis paniculata Franch. Env. Exp. Bot., 66: 126-134.

Li, Y., Zu, Y. Q., Fang, Q. X., Chen, H. Y. and Schvartz, C. 2013. Characteristics of heavy-metal tolerance and growth in two ecotypes of Oxyria sinensis Hemsl. grown on huize lead-zinc mining area in Yunnan Province, China. Commun. Soil Sci. Plan., 44(16): 2428-2442.

Yang, M. Y., Liang, Y. Y., Zeng, D. B., Chen, T., Chen, H., Liu, T. R. and Xing, J. Y. 2014. Effects of lead stress on accumulation capacity and physiological metabolism of ryegrass. Journal of Northwest A\&F University (Nat. Sci. Ed.)., 42(12): 97-101.

Wu, C., Liao, B., Wang, S. L., Zhang, J. and Li, J. T. 2010. Pb and Zn accumulation in a Cd-hyperaccumulator (Viola baoshanensis). Int. J. Phytoremediat., 12(6): 574-585.

Wu, B. Y., Shao, B. J., Zhao, H. E., Wang, X. M. and Mei, L. 2017. Cd accumulation and tolerance characteristics of 11 species in Sedum sensu lato. Acta Scientiae Circumstantiae, 37(5): 1947-1956.

Wang, X. L., Chang, Q. S., Hou, X. L., Lei, M. and Ma, Q. X. 2010. Heavy metal enrichment of plants at lead-zinc mines in south China. Ecology and Environmental Sciences, 19(1): 108-112 (in Chinese).

Wang, H. Q., Li, H. and Lu, S. J. 2005. Bidens maximowicziana's absorption and restoration potential to lead in soil. Environmental Science, 26(6): 143-147 (in Chinese). 